\title{
THE EFFECTS OF LABORATORY, PHARMACY, AND NUTRITION SERVICES ON SATISFACTION OF DIABETES MELLITUS PATIENTS
}

\author{
Nur Azizah'), Serlie K.A . Littik²), Sabina Gero²) \\ 1)Provincial Health Office Nusa Tenggara Timur \\ 2)Masters Program in Public Health, Universitas Nusa Cendana, Kupang
}

\begin{abstract}
Background: Patients' satisfaction reflects patients' perceptions and needs towards health service utilization. Poor patient satisfaction causes poor compliance to treatment which ultimately leads to poor health outcomes. The purpose of this study was to investigate the effects of laboratory, pharmacy, and nutrition services on satisfaction of diabetes mellitus patients.

Subjects and Method: A cross sectional study conducted at Prof. Dr. W.Z. Johannes, Kupang, East Nusa Tenggara. A sample of 32 DM inpatients was selected by quota sampling. The dependent variable was patient satisfaction. The independent variables were laboratory, pharmacy, and nutrition services. The data were collected by questionnaire. The data were analyzed by a multiple logistic regression.

Results: Good pharmacy service improved type II DM patient satisfaction ( $O R=1.23$; $95 \% \mathrm{CI}=0.31$ to $1.11 ; \mathrm{p}=0.167)$, but it was statistically non-significant. Poor laboratory service $(\mathrm{OR}=0.48 ; 95 \% \mathrm{CI}=0.33$ to $1.22 ; \mathrm{p}=0.199)$ and poor nutrition service $(\mathrm{OR}=$ $0.02 ; 95 \% \mathrm{CI}=0.17$ to $1.02 ; \mathrm{p}<0.001$ ) reduced type II DM patients satisfaction.

Conclusion: Good pharmacy service improves type II DM patient satisfaction, but it is statistically non-significant. Poor laboratory service and poor nutrition service reduces type II DM patient's satisfaction.
\end{abstract}

Keywords: type II diabetes mellitus, patient satisfaction

\section{Correspondence:}

Nur Azizah. Provincial Health Office, Jl. Palapa 22, Kupang, East Nusa Tenggara, Indonesia. Email: nurazizah9714@gmail.com Mobile: 081337331339.

The $6^{\text {th }}$ International Conference on Public Health

Best Western Premier Hotel, Solo, Indonesia, October 23-24, 2019 | 264

https://doi.org/10.26911/the6thicph.04.26 